\title{
Analisis Framing Pemberitaan Kebakaran Hutan dan Lahan di Riaupos.co dan Tribunpekanbaru.com periode 15-17 September 2019
}

\author{
Tutut Ismi Wahidar, Ringgo Eldapi Yozani \\ Fakultas Ilmu Sosial dan Ilmu Politik, Universitas Riau \\ tutut.ismiwahidar@lecturer.unri.ac.id
}

\begin{abstract}
Media nowadays has used the online system as a form of reporting the news. It has more benefits in providing an opportunity to have the latest news direct from the scene in comparison to the conventional systems. Especially for the local media who already utilised the digital system, the proximity (closeness) between local online media could be the advantages. Particularly when the disaster arose like haze disaster in Riau that occurred since mid July 2019 and it peaks on September 2019. This study discusses the framing of forest and land fires in Riau on Riaupos.co and Tribunpekanbaru.com on September 15-17, 2019. To reveal on how news framing of forest and land fires in Riau portrayed by Riaupos.co and Tribunpekanbaru.com, thedata is analysed with framing approach by Robert $N$ Entman with focusing on a selection of issues and emphasizing certain aspects of reality. The results revealed both medias have framed the forest and land fires news in Riau in differently. Tribunpekanbaru.com frames the issue on the impacts of forest and land fires and how it disrupted of community activities. While Riaupos.co presented the government sideof frame, portrayed governent's effort in handling the forest and land fire disaster. These differences in writing the news are motivated by the perspective divergence of each media. It can be seen from the medial journalist style in presenting the news that is based on discussion of problems, case diagnoses, morals, and solutions that must be taken.
\end{abstract}

Keywords: forest and land fires; framing; news; online media

\begin{abstract}
Abstrak
Saat ini, media telah menggunakan sistem online sebagai bentuk pelaporan. Hal ini bertujuan untuk memberikan kesempatan dalam pemberitaan yang teraktuaal dari lokasi kejadian dibandingkan dengan system konvensional. Begitu juga halnya dengan media lokal yang berbasis di setiap daerah juga sudah menggunakan sistem digital. Demikian juga halnya dengan media lokal yang berbasis disetiap daerah juga menggunakan sistem digital. Hal tersebut terjadi karena proximity (kedekatan) antara media online lokal. Seperti pada bencana kabut asap di Riau. Bencana kabut asap telah terjadi sejak pertengahan Juli hingga puncaknya terjadi pada September. Penelitian ini membahas framing kebakaran hutan dan lahan di Riau menurut media online Riaupos. co dan Tribunpekanbaru.com pada 15-17 September 2019. Penelitian ini menggunakan metode deskriptif kualitatif dengan analisis data yang digunakan adalah analisis framing Robert N. Entman dengan menyeleksi isu dan penekanan atau menyoroti aspek-aspek tertentu realitas tertentu, yang akan mengungkap bagaimana framing (pembingkaian) berita yang dilakukan oleh media online Riaupos.co dan Tribunpekanbaru.com untuk pelaporan kebakaran hutan dan lahan di Riau. Hasil penelitian menunjukkan bahwa kebakaran hutan dan lahan di Riau dibingkai secara berbeda. Tribunpekanbaru.com membingkai masalah dampak yang diakibatkan oleh kebakaran hutan dan lahan serta gangguan kegiatan masyarakat. Sementara itu, Riaupos.co menghadirkan kerangka sisi pemerintah dalam upaya mengatasi bencana kebakaran hutan dan lahan. Perbedaan dalam menulis berita dimotivasi oleh perbedaan dalam perspektif masing-masing media. Ini terlihat dari bagaimana jurnalis menulis berita yang disusun berdasarkan identifikasi masalah, diagnosa kasus, penilaian moral, dan solusi yang harus diambil.
\end{abstract}

Korespondensi: Tutut Ismi Wahidar, S.I.Kom., M.I.Kom, Jurusan Ilmu Komunikasi FISIP Universitas Riau, Jalan HR Subrantas KM.12,5 Simpang Baru, Pekanbaru, 28293, 08116533778, Alamat Email: tutut.ismiwahidar@lecturer.unri.ac.id

Menyerahkan: Februari 2020, Diterima: Juli 2020, Terbit: Juli 2020

ISSN: 2549-0559 (cetak), ISSN: 2549-1946 (online), Website: http://jurnal.unpad.ac.id/kajian-jurnalisme 
Volume 04 Nomor 01 Tahun 2020

DOI: $10.24198 /$ jkj.v4i1.26224

Kata kunci: Framing; Karhutla; Media online; Pemberitaan

\section{PENDAHULUAN}

Bencana kabut asap merupakan dampak negatif dari Kebakaran hutan dan Lahan (Karhutla) yang tidak terkendali dan dapat terjadi secara sengaja maupun tidak disengaja. Karhutla di Indonesia, sering terjadi di Provinsi Kalimantan Tengah, Provinsi Kalimantan Barat, Provinsi Kalimantan Selatan, Provinsi Sumatera Selatan, Provinsi Jambi dan terutama di Provinsi Riau (Kementrian Lingkungan Hidup dan Kehutanan, 2019). Kabut asap yang disebabkan oleh Karhutla ini dapat mencemari udara dan menjadi polusi terburuk serta mengganggu sistem pernapasan. Menurut data Badan Nasional Penanggulangan Bencana (BNPB) per 19 September 2019 pukul $09.00 \mathrm{WIB}$, tercatat, api telah membakar lahan seluas 328.724 hektare di seluruh Indonesia pada bulan Januari-Agustus 2019. Hal ini mengakibatkan Indeks Standar Pencemar Udara (ISPU) dinyatakan tidak sehat. Menurut BNPB sebaran titik api yang ada di sejumlah wilayah mencapai 4.077 titik (Putsanra, 2019).

Masalah karhutla merupakan masalah yang serius dan penanganannya haruslah serius pula. Masalah karhutla bukanlah masalah Indonesia saja tetapi juga masalah bagi negaranegara di sekitar daerah yang terjadi karhutla. Apabila dilihat dari letak geografisnya wilayah Riau merupakan provinsi di Indonesia yang memiliki batas wilayah yang langsung dan sangat berdekatan dengan negara tetangga seperti Melaka dari Malaysia dan juga Singapura, sehingga apabila terjadi karhutla di Riau maka negara-negara tetangga akan terkena dampaknya juga. Hal ini akan membuat nama Indonesia menjadi negative di dunia inetrnasional. Menurut pantauan dari Badan Meteorologi, Klimatologi dan Geofisika (BMKG) dikutip oleh tirto.id, asap karhutla tahun 2019 sudah sampai ke Thailand, Brunei Darussalam dan Filipina (Putsanra, 2019). Ini sangat merugikan negara tetangga karena beberapa penerbangan menjadi terhambat dan dialihkan.

Riau tercatat pernah mengalami karhutla di tahun 1997 yang mana asapnya telah sampai ke benua Australia dan menyebabkan beberapa kecelakan pesawat. Merujuk pada data Kementerian Lingkungan Hidup dan Kehutanan, dalam situs www.iku.menlhk.go.id, pada tanggal 19 September 2019 pukul 14.30 WIB, tercatat ISPU di Kota Pekanbaru, Riau mencapai 238. Hal ini masuk ke dalam kategori udara Sangat Tidak Sehat. Pada kasus karhutla di Riau, Kapolri pada saat itu menyatakan bahwa tersebut merupakan tindakan yang disengaja (Ma'ruf, 2019). Biasanya hutan dan lahan yang sengaja dibakar digunakan sebagai lahan baru untuk perkebunan (Khaviqain, 2019). Praktik karhutla sering terjadi pada musim kemarau karena api lebih mudah menyebar di musim itu sehingga tidak diperlukan banyak biaya dalam membuka lahan baru untuk areal perkebunan kelapa sawit

Faktor lain yang mendorong terjadinya karhutla berkepanjangan ialah kondisi lahan gambut di Riau. Lahan gambut itulah yang menjadi komposisi utama tanah di sebagian wilayah Riau dan menjadikan Riau sebagai daerah dengan lahan gambut terluas di Pulau Sumatera (Pujiono, 2015). Adanya topografi Riau yang demikian maka praktik karhutla menjadi lebih banyak dan lebih lama terjadi. Api yang lebih sulit dipadamkan karena turut membakar gambut yang menjadi komposisi utama tanah di Riau yang memiliki kedalaman lebih dari 1 meter di atas permukaan tanah. Karhutla sering dilakukan oleh oknum-oknum yang tidak bertanggungjawab sehingga berakibat pada perusakan lingkungan hidup.

Undang-Undang tentang Perlindungan dan Pengelolaan Lingkungan Hidup (UU PPLH) (Kementrian Hukum dan Hak Asasi Manusia Republik Indonesia, 2009), menerjemahkan lingkungan hidup sebagai kesatuan ruang dengan semua benda, daya, keadaan, dan makhluk hidup, termasuk manusia dan perilakunya, yang mempengaruhi alam itu sendiri, kelangsungan 
perikehidupan, dan kesejahteraan manusia serta makhluk hidup lain. Sedangkan perusakan lingkungan hidup berarti perusakan yang disengaja pada satu-kesatuan ekosistem, yang terdiri dari komponen biotik hingga abiotik yang turut ada didalamnya. Praktik karhutla tentu saja menjadi tindakan yang menyalahi dan bertentangan dengan UU PPLH.

Praktik karhutla tentunya membawa dampak bagi manusia sebagai komponen biotik dalam lingkungan hidup di masyarakat. Berdasarkan Peraturan Menteri Kehutanan Nomor: P.12/Menhut-II/2009, Karhutla adalah salah satu masalah lingkungan utama yang menyebabkan permasalah pada perekonomian, ekologi, dan sosial (Kementrian Kehutanan, 2009).. Karhutla sering terjadi akibat penggunaan api dalam pembukaan hutan dan lahan untuk difungsikan sebagai Hutan Tanaman Industri (HTI), perkebunan kelapa sawit, pertanian serta pembalakan liar (Forest Watch Indonesia, 2015).

Kebakaran hutan juga berdampak pada makhluk hidup lain seperti hewan-hewan yang berada di hutan tersebut juga menjadi korban. Terdapat empat dampak utama akibat karhutla yakni kerugian di sektor kesehatan, lingkungan, perekonomian, dan transportasi (Suryani, 2012).. Pada sektor kesehatan, masyarakat Riau kini terserang ISPA (Infeksi Saluran Pernafasan Akut) sehingga metabolisme dan daya tahan tubuh masyarakat menurun. Seperti yang diinformasikan oleh Tribun Pekanbaru, sejak awal September hingga 10 September 2019 telah tercatat 1.670 jiwa masyarakat Kabupaten Kampar yang terjangkit ISPA. Angka tersebut baru dari satu kabupaten di Riau dan belum menyeluruh. Menurut data dari Kementerian Kesehatan, penderita ISPA di Riau terhitung sejak 1-15 September 2019 telah mencapai 15.346 jiwa (Rubby, 2019)

Data-data mengenai sejumlah dampak yang diakibatkan oleh karhutla di Riau inilah yang dianggap perlu untuk diinformasikan kepada masyarakat luas. Media massa mempunyai peran yang sangat strategis sesuai dengan salah satu fungsinya, yaitu fungsi Informasi (Maranatha \& Kusmayadi, 2020). Informasi yang diberikan sebaiknya tidak hanya untuk masyarakat setempat atau Riau saja tetapi juga pada masyarakat di luar Riau yakni seluruh Indonesia. Untuk mendapatkan informasi selengkap-lengkapnya, media harus turun langsung ke lokasi yang terkena dampak bencana. Hal itu menjadi sebuah keterbatasan bagi media nasional karena tidak mampu mendapatkan informasi dengan segera. Berbeda dengan media online lokal yang dapat langsung meluncur dengan mudah menuju lokasi karhutla yang memudahkan informasi didapatkan dengan segera dan lebih jelas. Kemudahan bagi wartawan daerah yang sudah tahu daerah bencana menjadi nilai plus tersendiri, ditambah penguasaan bahasa lokal yakni bahasa Minang dan Melayu yang sudah menjadi bahasa sehari-hari oleh mereka memudahkan untuk berkomunikasi mencari informasi.

Dewasa ini perkembangan media sudah sangat berkembang dalam sistem pemberitaannya. Perkembangan dari sistem konvensional cetak ke sistem online yang tentunya akan dapat lebih mudah dalam proses pemberitaan. Media massa berbasis online bergerak lebih cepat karena kehadiran jaringan internet yang telah digunakan sebagai standar berkomunikasi dan lebih dikenal dengan new media atau media baru. Melalui media baru, informasi yang dihasilkan semakin berkembang dari segala aspek, baik kualitas maupun kuantitas. Melalui internet, kini siapa saja dapat mengakses berita kapanpun dan dimanapun.

Kelebihan internet yang mampu membantu proses penyebaran informasi dengan cepat tersebut dapat dirasakan oleh setiap manusia. Pasalnya kini internet telah berada digenggaman tangan manusia melalui handphone. Pada tahun 1962, muncul istilah global village yang digagas oleh McLuhan. McLuhan dalam istilah yang ia ciptakan tersebut memiliki pandangan bahwa perkembangan teknologi menjadi latar belakang mudahnya penyebaran informasi ke segala penjuru dunia (Pamungkas, 2017). 
Dilansir dari (Jayani \& Widowati, 2019) menunjukkan perkembangan jumlah pengguna internet yang semakin berkembang di Indonesia dari tahun 2017 ke tahun 2018 ialah sebesar $13,3 \%$ dari 84 juta pengguna menjadi 95,2 juta pengguna. Website tersebutjuga memproyeksikan bahwa perkembangan jumlah pengguna internet pada tahun 2019 tumbuh sebesar 12,6\% yaitu menjadi 107,2 juta pengguna.

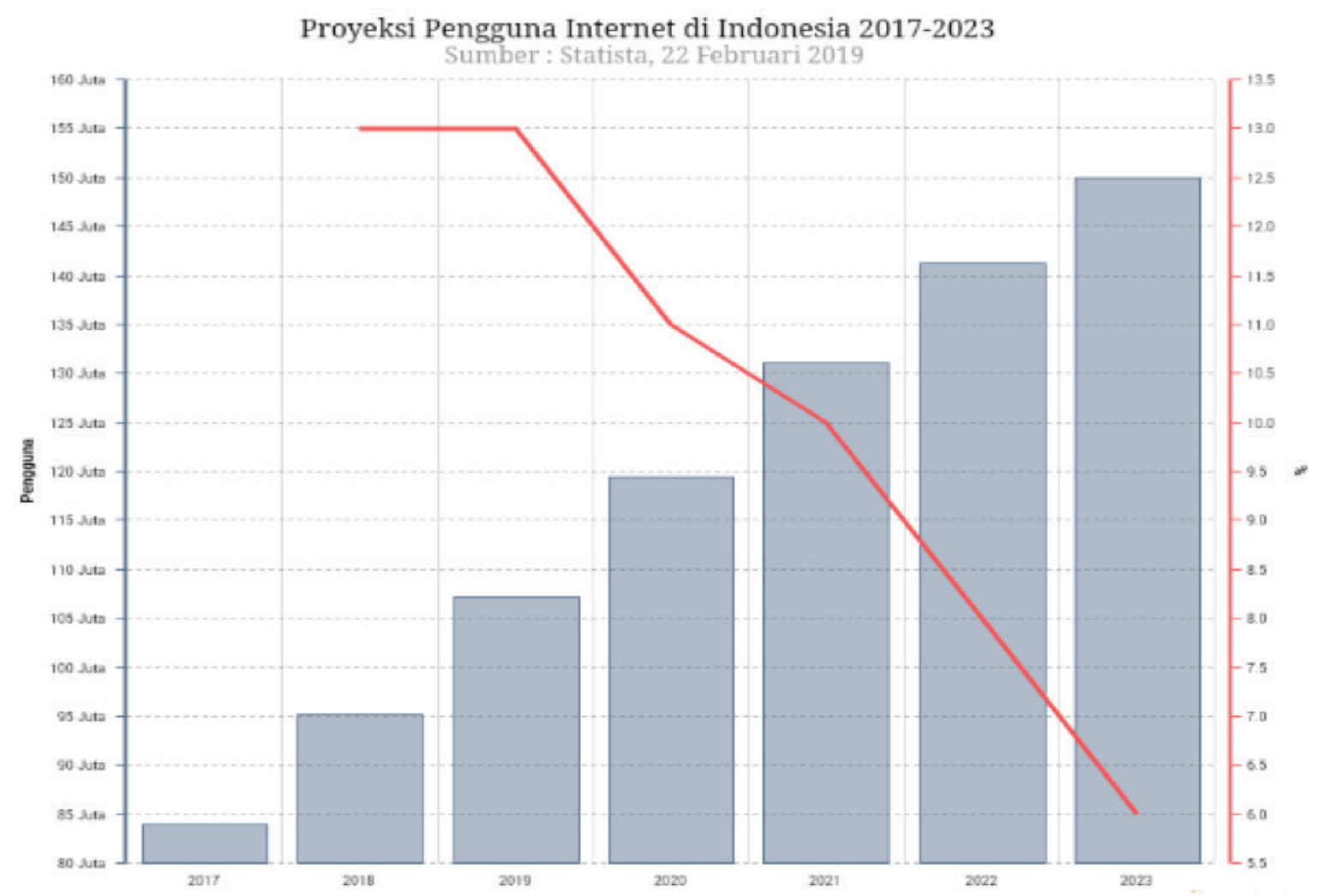

Gambar 1. Grafik yang menunjukkan penggunaan internet di tahun 2019. Sumber: Databoks.katadata.co.id (2019)

Berbeda dengan informasi yang dilansir dari kompas.com yang memproyeksikan peningkatan jumlah pengguna internet di Indonesia sejak tahun 2019 ialah sebesar 10,12\% dengan jumlah 171,17 jiwa (Pratomo, 2019). Peningkatan tersebut didapat berdasarkan hasil studi Polling Indonesia bersama Asosiasi Penyelenggara Jasa Internet Indonesia (APJII) selama periode Maret hingga April 2019.

Data pada gambar 2 menunjukkan lebih dari setengah penduduk Indonesia telah memiliki akses internet pribadi. Sebagai jalur informasi, internet dapat menghubungkan manusia dari satu tempat ke tempat lainnya tanpa terbatas pada jarak dan waktu. Semua bebas mengakses dan menyebarkan informasi kapan saja dan dimana saja. Perkembangan internet menuntut media massa untuk cepat dalam memberitakan suatu informasi kepada khalayak luas. Sejumlah media massa kini telah bertransformasi dengan menghadirkan laman online dari masing-masing media dan lebih dikenal sebagai media online. Lewat media online, media massa berlomba-lomba untuk menyiarkan suatu pemberitaan. Perkembangan media online di Indonesia mengalami kemajuan yag sangat pesat. Menurut Menteri Komunikasi dan Informatika, Rudiantara di tahun 2018 terdapat 43 ribu portal berita online. Sebagian portal online tersebut masih ada yang belum terverifikasi oleh Dewan Pers. Jumlah media online yang telah terverifikasi oleh Dewan Pers tidak lebih dari 100 media (Kementerian Komunikasi dan Informatika, 2018). 


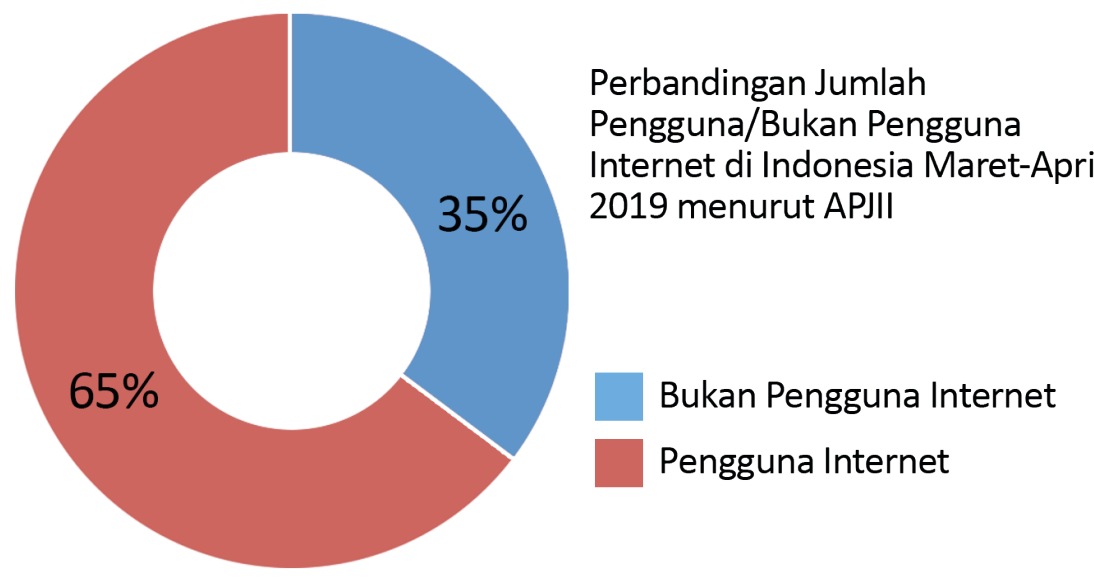

Gambar 2 Perbandingan Jumlah Pengguna/Bukan Pengguna Internet di tahun 2019. Sumber: olahan peneliti (2019)

Persaingan antar media massa lebih terasa terutama saat terjadinya suatu bencana pada suatu daerah. Media online lokal dalam hal ini memiliki kesempatan emas untuk memberitakan kondisi terkini dari lokasi kejadian, dibandingkan dengan media massa nasional. Hal ini karena adanya proximity (kedekatan) antara media online lokal dengan daerah bencana yang bukan hanya secara geografis tetapi juga kedekatan secara emosional, seperti yang terjadi di Riau. Bencana kabut asap telah terjadi sejak pertengahan Juli 2019 hingga puncaknya terjadi pada bulan September 2019. Fokus penelitian ini adalah pemberitaan tanggal 15 hingga 17 September 2019 karena pada tanggal tersebut adalah penjadwalan persiapan kedatangan Presiden Indonesia Joko Widodo untuk melihat langsung bencana kabut asap di Provinsi Riau yang sudah mencapai puncaknya.

Di antara sejumlah media lokal yang ada di Riau, terdapat dua media yang telah lama berdiri yaitu Riau Pos yang berdiri sejak tahun 1991 dan Tribun Pekanbaru yang berdiri sejak 2007. Kedua media tersebut adalah media yang sangat popular di Riau dan menjadi media lokal yang menjadi bahan referensi masyarakat Riau untuk mencari informasi. Keduanya media tersebut juga telah memiliki media online yakni Riaupos.co dan Tribunpekanbaru.com. Adanya media online yang diluncurkan oleh Riaupos.co dan Tribunpekanbaru.com mempermudah penyebaran informasi kepada masyarakat Riau dengan lebih cepat dan mudah tanpa harus membeli koran. Media massa lokal perlu dibentuk sebagai sarana pemenuhan informasi bagi masyarakat daerah tersebut (Maranatha \& Kusmayadi, 2020). Cukup dengan membuka gadget dimana pun dan kapan pun setiap waktu.

Media online (online media) disebut juga digital media, adalah media yang tersaji secara online di internet dan sering juga disebut media daring (dalam jaringan) (Romli, 2012). Istilah media daring masih belum sepopuler istilah media online dan media siber. Banyak kelebihan dari media online, salah satunya kemudahan bagi para jurnalis dapat mengirimkan berita yang didapat langsung ke meja redaksi hanya melalui e-mail atau media lainnya dengan cepat dan mudah dengan bantuan internet. Namun, karena Media online hingga saat ini masih menjadi enigmatic, konten dari pemberitaan media online juga harus berpedoman pada kode etik jurnalistik (Muliawanti, 2018). Berita yang disajikan tidak boleh tercampur antara fakta dan opini dari jurnalis sehingga menghasilkan berita yang obyektif, cover both side, serta fokus pada ketepatan dan kecermatan. 
Adanya perbedaan sudut pandang pengambilan berita dari media online Tribunpekanbaru. com dan Riaupos.co membuat penelitian ini menjadi menarik, sehingga layak untuk dianalisis lebih lanjut dan mendalam terhadap berita yang disajikan dengan lebih kompleks dan layak untuk dicermati dan diteliti. Melalui kedua media online tersebut peneliti berusaha melihat bingkai yang digunakan oleh kedua media. Pembingkaian suatu berita tidak terlepas dari sudut pandang dari masing-masing media tersebut. Ideologi apa yang kedua media tribunekanbaru. com dan Riaupos.co jalankan. Masing-masing memiliki sudut pandang, ideologi dan kekhasannya sendiri sehingga dalam melihat suatu peristiwa juga pasti akan berbeda.

Media merupakan penjaga gerbang informasi harus selektif dalam menyampaikan suatu berita. Media harus bisa melihat bagaimana suatu berita dilaporkan dan apa-apa saja yang harus dilaporkan sehingga apa yang masyarakat ketahui merupakan bentuk atau hasil dari bentuk seleksi informasi dari media. Menurut hasil observasi awal peneliti bahwa berita-berita yang ada di Tribunpekanbaru.com banyak menekankan tentang pemberitaan yang bersifat idealis. Hal ini terlihat dari terobosan-terobosan yang dilakukan oleh pimpinan Tribupekanbaru. com yang banyak memberikan pelatihan-pelatihan kepada jurnalis-jurnalis baik yang masih junior maupun yang sudah senior. Pelatihan-pelatihan jurnalistik yang dibuat untuk membantu para jurnalis menciptakan berita-berita yang mengutamakan cover both side atau berimbang. Adanya pelatihan-pelatihan ini diharapkan dapat meningkatkan kualitas dari isi media mereka yang mana wartawan Tribunpekanbaru.com tidak melihat suatu peristiwa hanya dari satu sudut pandang saja melainkan dari berbagai sudut pandang. Hal ini penting agar tidak adanya keberpihakan dalam suatu pemberitaan.

Visi media online Riaupos.co adalah "menjadi perusahaan multimedia terdepan dan terkemuka di Sumatera", misi "Ikut serta mencerdaskan kehidupan berbangsa, serta motto "bangun negeri bijakan bangsa". Menurut hasil penelitian yang sudah dilakukan oleh Hefri Yodiansyah bahwa Riapos.co dalam menyampaikan berita-beritanya dipengaruhi oleh faktorfaktor ideologi perusahaan serta lebih mempertimbangkan pangsa pasar (ekonomi). Hal ini terlihat dari berita-berita yang dimuat Riaupos.co yang bermuatan dukungan massa terhadap pemerintah (Hefri Yodiansyah Sekolah, 2017).

Merujuk pada penelitian yang sudah dilakukan oleh Hefri, peneliti sangat tertarik meneliti bagaimana pembingkaian berita karhutla dari kedua media tersebut. Penelitian Hefri melihat isu-isu politik di kedua media tersebut sedangkan fokus penelitian ini melihat pembingkaian dari isu-isu tentang karhutla, yakni media Riaupos.co dan Tribunpekanbaru.com. Preposisi ini dibangun mengingat karakteristik media online yang menuntut adanya kecepatan dalam mengunggah berita mendorong jurnalis untuk mengunggah informasi utama yang menjawab $5 \mathrm{~W}+1 \mathrm{H}$. Preposisi tersebut yang ingin dikaji dalam penelitian ini melalui penelitian analisis framing media online terhadap pemberitaan karhutla (kebakaran hutan dan lahan) di Riaupos.co dan Tribunpekanbaru.com periode 15-17 september 2019 diberitakan. Adapun yang menjadu Maksud dan tujuan penelitian ini sesuai dengan masalah dalam penelitian ini adalah untuk mengetahui framing dari Entmant mengungkap masalah kependefinisian masalah, diagnosa masalah, keputusan moral dan rekomendasi. Sebagai media dengan pengunjung terbanyak sekitar 1.668,789 dalam beberapa bulan terakhir membuat Tribunpekanbaru.com menjadi urutan pertama dalam media online di Riau yang dipercaya oleh pembacanya, sampai sekarang jumlah pengunjung media online tersebut terus bertambah.

Define Problems (pendefinisian masalah). Elemen ini merupakan bingkai yang paling utama yakni bagaimana peristiwa atau isu dipahami oleh wartawan. Peristiwa yang sama dapat dipahami secara berbeda dan bingkai yang berbeda ini akan menyebabkan realitas bentukan yang berbeda. Diagnose Causes (memperkirakan penyebab masalah). Elemen ini merupakan 
elemen untuk membingkai siapa yang dianggap sebagai aktor dari suatu peristiwa. Penyebab disini bisa berarti apa (what), atau juga siapa (who). Make Moral Judgement (membuat pilihan moral). Elemen yang dipakai untuk membenarkan/memberikan argumentasi pada pendefinisian masalah yang telah dibuat. Ketika masalah sudah didefinisikan, penyebab masalah sudah ditentukan, dibutuhkan sebuah argumentasi yang kuat untuk mendukung gagasan tersebut. Treatment Recommendation (menekankan penyelesaian). Dipakai untuk menilai apa yang dikehendaki oleh wartawan. Jalan apa yang dipilih untuk menyelesaikan masalah (Eriyanto, 2011). Keempat elemen diatas adalah elemen-elemen yang dibagi oleh Robert N. Entmant untuk menganalisa suatu wacana yang mendasar untuk menekankan kerangka berpikir tertentu terhadap peristiwa yang diwacanakan secara framing (Eriyanto, 2012). Keempat elemen ini juga yang digunkan peneliti untuk menganalisa pembingkaian berita di media online Tribunpekanbaru.com dan Riaupos.co dalam menyajikan berita.

\section{METODE}

Pada penelitian ini digunakan jenis penelitian kualitatif dan menggunakan pendekatan atau paradigma konstruksionis. Paradigma konstruksionis memandang bahwa tidak ada realitas yang objektif, karena realitas tercipta melalui proses konstruksi dan pandangan tertentu. Metode penelitian ini digunakan untuk melihat gambaran konstruksi tertentu dari sebuah realitas dalam hal ini sebuah peristiwa yang dibingkai oleh media online Riaupos.co dan Tribunpekanbaru. com menjadi sebuah berita yang kemudian menjadi realitas media dalam pemberitaan Karhutla periode 15-17 September 2019, sebanyak 9 berita untuk Riaupos.co dan 12 berita untuk Tribunpekanbaru.com. Berita tersebut adalah objek yang dianalisis menggunakan metode framing Entmant. Deskriptif kualitatif untuk menggambarkan, meringkas berbagai kondisi, situasi, atau fenomena realitas sosial dalam masyarakat yang menjadi objek penelitian dan berupaya menarik realitas itu ke permukaan sebagai suatu ciri, karakter, sifat, model, tanda, atau gambaran tentang kondisi, situasi, ataupun fenomena tertentu (Bungin, 2011)

Penelitian ini menggunakan metode analisis framing model Robert N. Entman. Bagaimana suatu peristiwa disajikan oleh media, seperti apa sudut pandang media terhadap suatu peristiwa dapat dilihat melalui analisis framing. Penelitian ini memiliki lokasi yaitu media online Riaupos.co dan Tribunpekanbaru.com dengan alamat website resmi yaitu https:// riau.co dan https://Tribunpekanbaru.com. Berdirinya Riaupos.co dimulai tahun 2005 dan menjadi salah satu media online terbesar yang ada di Provinsi Riau, yang beralamat di Gedung Graha Pena Riau Lt 3, Jl Hr. Soebrantas KM. 10,5 Panam, Sidomulyo Barat, Tampan Kota Pekanbaru 28000. Berdiri pertama kali dengan nama Riaupos.co dan dirubah menjadi Riaupos. co di tahun 2010. Pada tahun 2015, Riaupos.co memutuskan untuk memisahkan diri dari Riau Pos dan membentuk manajemen sendiri, yaitu PT. Riaupos Multimedia Korporasindo. Tujuan dibentuknya Riaupos.co online adalah untuk menopang Riau Pos cetak dalam menyampaikan informasi.

Pada umumnya di zaman era digital minat membaca koran kurang diminati oleh masyarakat terutama generasi milenial. Riaupos melebarkan sayapnya melahirkan Riaupos.co yang diharapkan dapat menyebarkan informasi kepada masyarakat lebih cepat dan menyasar pangsa pasar kaum muda yang banyak menghabiskan waktu dengan menggunakan smartphone. Semakin meningkatnya kebutuhan akan informasi pada masyarakat yang berada di luar Provinsi Riau dan ingin mengetahui perkembangan Provinsi Riau juga turut andil melahirkan media online ini. Mencari informasi tentang daerah Riau dapat dengan mudah dilakukan melalui gadget yang sudah dimiliki oleh hampir semua kalangan masyarakat, mulai dari yang kaya maupun yang kalangan menengah ke bawah, dari yang tua ke yang muda. Hal ini dapat 
dilakukan dimana pun dan kapan pun berada. Apalagi dengan menjamurnya lokasi-lokasi dan kafe-kafe yang menyediakan saran wifi gratis bagi pelanggannya, ditambah lagi harga kuota internet yang sudah tidak terlalu mahal.

Tribun Pekanbaru adalah surat kabar yang berdiri pada 18 April 2007, dengan motto "Spirit Baru Riau" sebagai media yang independen dan kredibel, Tribun Pekanbaru selalu menampilkan perkembangan berita terbaru ke publik. Setelah satu tahun berdiri, Tribun Pekanbaru melebarkan sayapnya ke media online. Media yang beralamat di Jl. Imam Munandar (Harapan Raya) No.383 Kecamatan Bukitraya Pekanbaru ini meluncurkan Tribunpekanbaru. com yang dibawahi oleh tribunnews.com dengan domain akses pekanbaru.tribunnews.com. Bertujuan agar masyarakat dapat dengah mudahnya mendapatkan informasi dan dapat memilih sendiri informasi apa yang mereka inginkan.

Di usianya yang memasuki delapan tahun, Tribun Pekanbaru sudah mampu menyaingi pendahulunya yakni Riau Pos Grup dan termasuk dalam 29 koran lokal lainnya yang ada di Riau. Para pembaca Tribun Pekanbaru sudah tersebar di seluruh daerah di Riau. Presentase pembaca pada Tribun Pekanbaru yakni pria $60 \%$ dan wanita $40 \%$ berada di Pekanbaru, Kuantan Singingi, Indragiri Hilir, Kampar, Siak, Rokan Hulu, Dumai, Rokan Hilir, Pelalawan, Bengkalis, Duri, dan Kepulauan Meranti. Tribun Pekanbaru memiliki segmen pasar kalangan menengah ke atas, yakni kalangan ekonom, ormas, akademisi, para politisi, eksekutif, legislatif, yudikatif, pemberi kebijakan-kebijakan publik, publik figur dan tokoh-tokoh popular lainnya.

Menurut hasil wawancara yang peneliti lakukan kepada korlip wartawan senior Tribunpekanbaru febri dan dikuatkan oleh penelitian terdahulu oleh Herfi Yodiansyah di tahun 2017. Tribunpekanbaru memiliki gaya penulisan yang mengedepankan unsur human interest yaitu peristiwa yang menyentuh hati manusia atau lebih sering disebut konsep mikro people. Kompas Gramedia Grup melalui pers daerahnya (Persda) bersaing dengan koran-koran daerah dan melahirkan koran-koran daerah yang mencapai 16 buah surat kabar. Koran-koran tersebut antara lain: Tribun Lampung, Serambi Indonesia, Pos Kupang, Tribun Batam, Banjarmasin Pos, Sriwijaya Pos, Tribun Pontianak, Prohaba, Bangka Pos, Tribun Jabar, Pos Belitung, Metro banjar, Tribun Jambi dan Tribun Pekanbaru.

Waktu pada penelitian ini adalah sejak tanggal 15 September 2019 - 17 September 2019. Subjek penelitian, yaitu orang atau lembaga yang dipilih untuk diwawancarai atau diobservasi sesuai tujuan riset (Kriyantono, 2012). Pada penelitian ini yang menjadi subjek penelitian adalah media online Riaupos.co dan Tribunpekanbaru.com.

Teknik pengumpulan data dengan dokumentasi yang peneliti gunakan dalam penelitian ini adalah adalah dokumen pemberitaan dari masing-masing media online tersebut. Teknik pengumpulan data dengan dokumentasi adalah sebuah cara yang dilakukan untuk menyajikan dokumen-dokumen dengan menggunakan bukti yang akurat dari pencatatan sumber-sumber informasi khusus dari karangan/tulisan, wasiat, buku, undang-undang, foto/video dan sebagainya (Bungin, 2011). Dalam penelitian ini peneliti mengumpulkan berbagai macam dokumentasi dalam bentuk pemberitaan pada situs online Riaupos.co dan Tribunpekanbaru. com yang memberitakan tentang karhutla di tanggal 15-17 September 2019. Pemilihan tanggal 15-17 September adalah persiapan Presiden Joko Widodo untuk meninjau langsung lokasi karhutla di Riau, rapat internal beliau dengan pejabat-pejabat daerah hingga persiapan kembali pulang ke Jakarta sehingga penulis merasa ingin tahu dan ingin melihat pemberitaan yang ada di kedua media online tersebut. Apakah kedatangan Presiden Indonesia Bapak Jokowi dapat mempengaruhi pemberitaan yang dimuat di Riaupos.co dan Tribunpekanbaru.com dalam memberitakan pemberitaan karhutla di Riau tahun 2019.

Validitas dipakai sebagai ukuran apakah data yang didapat valid atau tidak. Validitas 
Volume 04 Nomor 01 Tahun 2020

DOI: $10.24198 /$ jkj.v4i1.26224

adalah kualitas hasil penelitian yang akan membawa seseorang untuk menyakini fakta-fakta yang ada tidak dapat ditentang. Alat ukur untuk mengukur apa yang didesain untuk diukur, dan menganggap analisis ini valid sejauh inferensinya didasarkan atas dasar pembuktian yang dicapai secara independent (Eriyanto, 2011). Data dapat dikatakan valid apabila tidak ada perbedaan antara apa yang dilaporkan peneliti dengan apa yang terjadi sesungguhnya pada objek yang diteliti, ini adalah penejelasan dalam validitas dalam penelitian kualitatif. Pada penelitian ini data yang dapat dikatakan valid karena peneliti mengambil data dari sumber yang tepat dan benar yaitu alamat website "Riaupos.co dan Tribunpekanbaru.com" dan penulis juga melakukan wawancara kepada wartawan Tribunpekanbaru.com dan Riaupos.co untuk memastikan keabsahan dari temuan peneliti.

\section{HASIL DAN PEMBAHASAN}

Berdasarkan hasil observasi awal yang peneliti amati bahwasanya berita mengenai karhutla sebelum tanggal 15-17 September 2019 memiliki kuantitas pemberitaan tentang karhutla yang banyak dengan judul-judul yang bombastis sedangkan setelah kedatangan Presiden kuantitas pemberitaan menjadi sedikit menurun dengan judul-judul pemberitaan yang relative menggunakan bahasa yang informatif mengenai kinerja pemerintah dalam penangan karhutla untuk Riaupos.com sedangkan untuk Tribunpekanbaru.com menggunakan bahasabahasa yang memberikan solusi dalam penangan karhutla.

Ketentuan pemberitaannya adalah sebagai berikut: Berita yang dianalisis peneliti adalah berita yang berasal dari situs resmi media online Riaupos.co dan Tribunpekanbaru.com yang diambil langsung oleh peneliti dari dengan mesin pencarian https://riau.co dan https:// Tribunpekanbaru.com. Berita yang dianalisis adalah berita tentang karhutla yang terjadi di Riau pada tanggal 15-17 September 2019. Berita karhutla dari kedua media online tersebut disusun dan di analisis sesuai dengan urutan tanggal pemberitaan yang di upload di kedua media online tersebut sesuai dengan tanggal yang sudah ditetapkan.

Peneliti membuat susunan kronologi pemberitaan secara berurutan yang dapat dilihat pada table di bawah ini:

Tabel 1. Perbedaan Sudut Pandang Antara Riaupos.co dan Tribunpekanbaru.com

\begin{tabular}{|c|l|l|l|}
\hline No & \multicolumn{1}{|c|}{ Tempat } & \multicolumn{1}{|c|}{ Judul Riaupos.co } & \multicolumn{1}{c|}{ Judul Tribunpekanbaru.com } \\
\hline 1 & 15 September 2019 & $\begin{array}{l}\text { Pemerintah lamban tangani asap, } \\
\text { mahasiswa dan masyarakat Riau } \\
\text { protes }\end{array}$ & $\begin{array}{l}\text { Karhutla } \\
\text { Riau Dibakar Bukan Terbakar". Mas- } \\
\text { yarakat Riau di Jakarta Gelar Aksi Kepri- } \\
\text { hatinan Karhutla Riau }\end{array}$ \\
\hline 2 & 15 September 2019 & $\begin{array}{l}\text { Kabut asap ancam lautan, nakhoda } \\
\text { kapal diminta waspada }\end{array}$ & $\begin{array}{l}\text { Karhutla } \\
\text { Update penanganan karhutla di Riau 15- } \\
\text { 09-2019 Pukul 10.00 WIB jarak pandang } \\
\text { 1 KM }\end{array}$ \\
\hline 3 & 15 September 2019 & & $\begin{array}{l}\text { Kabut asap semakin pekat dan menyengat, } \\
\text { alat pemurni udara (air purifier) bisa jadi } \\
\text { pertimbangan. }\end{array}$ \\
\hline 4 & 15 September 2019 & & $\begin{array}{l}\text { Kisah pemadam kebakaran hutan dan lah- } \\
\text { an di Riau: bertemu harimau, king kobra, } \\
\text { hingga sarang tawon }\end{array}$ \\
\hline 5 & 15 September 2019 & & $\begin{array}{l}\text { Kisah pemadam kebakaran hutan dan } \\
\text { lahan di Riau: dua bungkus mie instan bisa } \\
\text { untuk berlima }\end{array}$ \\
\hline 6 & 15 September 2019 & & $\begin{array}{l}\text { Berikut daftar penerbangan Lion Air, } \\
\text { Batik, dan Wings yang alami gangguan } \\
\text { karena kabut asap }\end{array}$ \\
\hline
\end{tabular}

Analisis Framing Pemberitaan Kebakaran Hutan dan Lahan di Riaupos.co dan Tribunpekanbaru.com periode 15- 
Volume 04 Nomor 01 Tahun 2020

DOI: $10.24198 / \mathrm{jkj} . \mathrm{v} 4 \mathrm{i} 1.26224$

\begin{tabular}{|c|c|c|c|}
\hline 7 & 15 September 2019 & & $\begin{array}{l}\text { Kabut asap makin parah, Garuda Indonesia } \\
\text { batalkan } 12 \text { penerbangan dengan alasan } \\
\text { keselamatan }\end{array}$ \\
\hline 8 & 16 September 2019 & $\begin{array}{l}\text { Lintas komunitas bagikan masker } \\
\text { gratis }\end{array}$ & $\begin{array}{l}\text { Jokowi ke Riau } \\
\text { Presiden RI Jokowi langsung rapat terbatas } \\
\text { setelah sampai di Riau, media lokal dila- } \\
\text { rang mendekat }\end{array}$ \\
\hline 9 & 16 September 2019 & $\begin{array}{l}\text { Jokowi disambut asap setiba di } \\
\text { Pekanbaru }\end{array}$ & $\begin{array}{l}\text { Jokowi ke Riau } \\
\text { Presiden RI Jokowi ke Riau, boyong } \\
\text { sejumlah Menteri tinjau karhutla di Riau, } \\
\text { ada Wiranto }\end{array}$ \\
\hline 10 & 16 September 2019 & $\begin{array}{l}\text { Efek kabut asap, jam ASN dise- } \\
\text { suaikan }\end{array}$ & $\begin{array}{l}\text { Jokowi ke Riau } \\
\text { Presiden RI Jokowi langsung rapat terbatas } \\
\text { setelah sampai di Riau, media lokal dila- } \\
\text { rang mendekat }\end{array}$ \\
\hline 11 & 17 September 2019 & $\begin{array}{l}10 \text { izin perusahaan terancam dicab- } \\
\text { ut diduga terlibat kebakaran hutan } \\
\text { lahan }\end{array}$ & $\begin{array}{l}\text { Soal Karhutla, Wiranto sebut tanggung- } \\
\text { jawab daerah, tugas pemerintah pusat } \\
\text { hanya ini }\end{array}$ \\
\hline 12 & 17 September 2019 & $\begin{array}{l}\text { Cegah karhutla, jangan tergantung } \\
\text { pusat }\end{array}$ & $\begin{array}{l}\text { Breaking News: Jokowi didampingi sejum- } \\
\text { lah Menteri tiba di desa merbau Kabupaten } \\
\text { Pelalawan Riau }\end{array}$ \\
\hline 13 & 17 September 2019 & $\begin{array}{l}\text { Mahasiswa tuntut penyelesaian } \\
\text { kabut asap }\end{array}$ & \\
\hline 14 & 17 September 2019 & $\begin{array}{l}\text { Kerja efektif, KLHK lakukan } \\
\text { penegakan hukum sekaligus upaya } \\
\text { pencegahan dan pemadaman kar- } \\
\text { hutla }\end{array}$ & \\
\hline
\end{tabular}

Sumber: Tribunpekanbaru.co dan Riaupos.com: Peneliti (2019)

Dapat dilihat dari tabel di atas bahwa pada media online Riuapos.co di tanggal 15 hanya mengupload 2 berita saja sedangkan dan Tribunpekanbaru.com memberitakan berita tentang asap sebanyak 7 berita. Beritanya pun diambil. Ada sudut pandang yang sama pada berita ditanggal 15 September 2019 tersebut dari kedua media online itu yakni sama-sama memberitakan bentuk protes masyarakat terhadap kabut asap dan adanya kritikan kepada pemerintah dalam hal penanganan oknum dan korporasi pembakar lahan. Pada berita yang kedua dari Riaupos.co lebih membahas tentang dampak yang ditimbulkan akibat karhutla, sedangkan di Tribunpekanbaru.com lebih membahas tentang penjelasan fakta di lapangan tentang tingkat kualitas udara di Pekanbaru. Tribunpekanbaru juga membahas tentang tips ringan yang dapat dilakukan masyarakat untuk sedikit mengurangi polusi udara. Berita pada tanggal itu pun juga banyak bercerita tentang pengalaman dari para petugas gabungan pemadam kebakaran yang tetap semangat untuk memadamkan api walau nyawa taruhannya.

Berita di Riaupos.co dan Tribunpekanbaru.com di tanggal 16 September 2019 samasama hanya mengupload 3 berita saja. Di tanggal ini dijadwalkan Presiden RI akan mendarat di Pekanbaru. Berita yang disajikan oleh kedua media online ini pun beragam. Riaupos.co membahas tentang komunitas yang ada di Pekanbaru mulai menunjukkan kepeduliannya, membahas kedatangan Presiden RI di Pekanbaru, dan dampak dari kabut asap membuat aktivitas warga terganggu. Tribunpekanbaru.com mengambil sudut pandang berita mengenai Presiden RI yang membawa beberapa pejabat pusat dan langsung melakukan rapat internal kepada seluruh pejabat pusat dan daerah, sehingga melarang wartawan lokal meliput,

Berita di tanggal 17 September 2019 dari Riaupos.co ada 4 berita sedangkan untuk Tribunpekanbaru.com ada 2 berita. Berita yang diangkat oleh Riaupos.co mengenai hukuman terhadap korporasi atau perorangan yang membakar lahan, keberhasilan dan upaya KLHK untuk memadamkan api, komentar Wiranto terhadap karhutla serta tuntutan mahasiswa yang 
masih saja bergulir sampai kedatangan Presiden RI. Untuk berita di Tribunpekanbaru.com lebih soft yakni tentang peninjauan lokasi karhutla oleh Jokowi dan jajaran serta komentar dari Wiranto tentang karhutla di Riau.

Pemberitaan Riaupos.co di hari pertama hanya mengupload 2 berita mengenai bentuk protes masyarakat dan adanya kritikan pada pemerintah. Hal yang sama juga terjadi pada Tribunpekanbaru.com, dimana banyak berita yang diturunkan yakni 8 berita mengenai karhutla yakni berita berupa data dan fakta tentang tingkat polusi udara di Pekanbaru, dampak karhutla yang menyebabkan pengalihan dan pembatalan dari sejumlah maskapai penerbangan, tips ringan untuk memurnikan udara, serta kisah-kisah heroik di balik petugas pemadaman api di lahan yang terbakar.

Ditanggal 16 September 2019 berita dari Riaupos.co naik menjadi 3 berita sedangkan Tribunpekanbaru turun menjadi 3 berita. Riaupos.co memberitakan dampak kabut asap menghalangi aktivitas warga sedangkan di Tribunpekanbaru memberitakan tentang bukti upaya-upaya pemerintah pusat dan daerah dalam menangani karhutla. Di tanggal 17 September brita yang diturunkan Riaupos.co naik menjadi 4 berita, yang mana isi dari pemberitaan tersebut adalah upaya pemerinta dalam menangani karhutla serta masih adanya bentuk protes mahasiswa tentang penanganan karhutla Riau. Di Tribunpekanbaru.com sendiri berita yang diturunkan di tanggal itu turun menjadi 2 berita saja, yang mana beritanya mengenai pemerintah pusat yang sedang menjalankan tugasnya dalam menangani masalah karhutla.

Perbedaan dalam memberitakan suatu peristiwa tidak terlepas dari pembingkaian (framing) dari masing-masing media online Tribunpkenbaru.com dan Riaupos.co. Hal ini berkaitan dengan ideologi dari masing-masing media. Perbedaan ini pun terlihat dari banyak hal dalam pemberitaan. Pemilihan sudut pandang, penulisan berita, pemilihan judul dan diksi, tampilan foto, grafis, dan lain sebagainya. Dalam penelitian ini yang paling terlihat jelas pemilihan sudut pandang yang ditelaah berdasarkan analisis framing dari Robert N. Entmant. Berdasarkan hasil penelitian, peneliti dapat menganalisis sudut pandang kedua media online ini berbeda.

Pada define problems (pendefinisian masalah) terlihat Tribunpekanbaru.com mengambil isu protes masyarakat dimana salah satu artikel berbunyi: "kepada Bapak Jokowi selaku Presiden agar menjadikan bencana kabut asap ini menjadi bencana nasional sehingga ada aksi nyata dari pemerintah pusat untuk menangani asap sebagaimana janji-janji Pak Jokowi dulu”. Kata Rusli. Membahas dampak kebakaran hutan dari segi ekonomi tetapi juga mengangkat isuisu yang berkaitan dengan solusi ringan untuk masyarakat agar tidak hanya berpangku tangan menunggu kinerja dari pemerintah daerah dan pemerintah pusat tetapi melakukan sesuatu yang bermanfaat. Dalam pemuatan isu seperti ini Tribunpekanbaru.com tidak hanya memberikan kritik dan fakta yang ada di lapangan saja tetapi memberikan sedikit ketenangan pada masyarakat dengan mengangkat isu-isu yang berkenaan dengan adanya "solusi" pada suatu peristiwa. Pada Riaupos.co, isu yang diangkat mengenai dampak karhutla, bentuk kepedulian masyarakat dan kinerja yang sudah dilakukan oleh pemerintah setelah kedatangan Presiden Jokowi.

Diagnose Causes (memperkirakan penyebab masalah) yang dilakukan oleh Tribunpekanbaru.com yaitu melihat objek dari karhutla berbeda. Sebelum kedatangan Presiden Jokowi, aktor dalam pemberitaan di Tribunpekanbaru.com lebih mengarah kepada fakta yang mana pembakaran hutan oleh oknum atau perusahaan yang sengaja membakar bukan kejadian bencana alam yang tidak disengaja. Kedua, objek pemberitaan kemudian mengarah kepada para petugas pemadam kebakaran dan relawan dalam memadamkan api serta "solusi" ringan untuk masyarakat. Setelah kedatangan Presiden Jokowi, objek pemberitaan lebih kepada siapa penanggungjawab karhutla. Pada Riaupos.co, objek pemberitaan tentang kritik terhadap 
pemerintah daerah yang lamban dalam menangani karhutla sehingga mengakibatkan demo besar-besaran dari mahasiswa. Setelah kedatangan Presiden Jokowi, objek pemberitaan lebih ringan yakni berisi tentang kewajiban penanganan karhutla yang tidak boleh hanya bergantung pada pemerintah pusat serta kepedulian komunitas pada masyarakat yang berdampak kabut asap. Seperti pada salah satu petikan wawancara dari Riaupos.co, "ini tanggungjawab daerah. Jangan terus bergantung pada pusat. Harus betul-betul tahu masalah ini dan tahu harus berbuat apat", ujar Wiranto.

Make Moral Judgement (membuat pilihan moral) yang dilakukan Tribunpekanbaru yaitu diarahkan kepada kabut asap yang seharusnya tidak membuat masyarakat kesusahan dari segi kesehatan dan ekonomi. Menampilkan sikap heroik para relawan dan pemadam kebakaran tapi yang tidak disertai dengan kepedulian pemerintah daerah dan pusat. Dimana masingmasing saling menyalahkan. Pilihan moral yang diangkat oleh Riaupos.co adalah efek dari kabut asap karhutla membuat orang terganggu dalam kesehatan, pendidikan dan pekerjaan. Usaha pemerintah daerah dan lembaga-lembaga pelestarian lingkungan dalam menyelesaikan masalah karhutla dimana sudah ada beberapa perusahaan yang terancam dicabut surat izinnya.

Treatment Recommendation (menekankan penyelesaian) yang dilakukan oleh Tribunpekanbaru.com bahwa kabut asap sangat mengganggu aktivitas warga dalam pekerjaan pendidikan, dan mengganggu kesehatan sehingga banyak mahasiswa yang berdemonstrasi untuk menuntut penyelesaian tersebut. Tetapi solusi lain yang angkat oleh Tribunpekanbaru. com adalah mengajak masyarakat untuk lebih mandiri. Terlihat dari pengangkatan isu tentang solusi tentang bencana kabut asap juga memberi peluang usaha bagi beberapa penjual alat pembersih udara yang sangat laku dipasaran karena bencana ini. Ada cerita positif dan negatif dari suatu peristiwa membuat ideologi Tribunpekanbaru.com terlihat jelas seperti pada penelitian sebelumnya oleh Herfi Yodiansyah di tahun 2017 yang sudah dijelaskan di latar belakang. Di Riaupos.co penekanan penyelesaian dari karhutla ini terletak dari sikap kepedulian masyarakat yang membagikan masker, tindak perusahaan yang melakukan pembakaran lahan.

\section{SIMPULAN}

Pengungkapan pendefinisian masalah dalam pemuatan isu seperti ini Tribunpekanbaru. com tidak hanya memberikan kritik dan fakta yang ada di lapangan saja tetapi memberikan sedikit ketenangan pada masyarakat dengan mengangkat isu-isu yang berkenaan dengan adanya "solusi" pada suatu peristiwa. Pada Riaupos.co, isu yang diangkat mengenai dampak karhutla, bentuk kepedulian masyarakat dan kinerja yang sudah dilakukan oleh pemerintah setelah kedatangan Presiden Jokowi. Diagnose Causes pada Tribunpekanbaru.com mengarah pada fakta pembakaran hutan oleh oknum atau perusahaan yang sengaja membakar bukan kejadian bencana alam yang tidak disengaja. Gaya penulisan Tribunpekanbaru.com juga mengedepankan human interest terlihat dari berita mengenai para petugas pemadam kebakaran serta "solusi" ringan untuk masyarakat. Setelah kedatangan Presiden Jokowi, objek pemberitaan lebih kepada siapa penanggungjawab karhutla. Pada Riaupos.co, objek pemberitaan tentang kritik terhadap pemerintah daerah yang lamban dalam menangani karhutla sehingga mengakibatkan demo besar-besaran dari mahasiswa. Setelah kedatangan Presiden Jokowi, objek pemberitaan lebih ringan berisi kewajiban penanganan karhutla yang tidak boleh hanya bergantung pada pemerintah pusat serta kepedulian komunitas pada masyarakat yang berdampak kabut asap.

Make Moral Judgement (membuat pilihan moral) yang dilakukan Tribunpekanbaru.com yaitu diarahkan kepada kabut asap yang seharusnya tidak membuat masyarakat kesusahan dari segi kesehatan dan ekonomi. Human interest para relawan dan pemadam kebakaran, sedangkan Riaupos.co adalah efek dari kabut asap karhutla membuat orang terganggu dalam kesehatan, 
Volume 04 Nomor 01 Tahun 2020

DOI: $10.24198 / j k j . v 4 i 1.26224$

pendidikan dan pekerjaan. Usaha pemerintah daerah dan lembaga-lembaga pelestarian lingkungan dalam menyelesaikan masalah karhutla dimana sudah ada beberapa perusahaan yang terancam dicabut surat izinnya.

Treatment Recommendation (menekankan penyelesaian) yang dilakukan oleh Tribunpekanbaru.com adalah mengangkat solusi untuk mengajak masyarakat untuk lebih mandiri. Cerita positif dan negatif dari suatu peristiwa memperlihatkan ideologi dari Tribunpekanbaru.com. Di Riaupos.co penekanan penyelesaian dari karhutla ini terletak dari sikap kepedulian masyarakat yang membagikan masker, tindak perusahaan yang melakukan pembakaran lahan.

Dari pembahasan di atas maka dapat disimpulkan bahwa ada penyusunan berita yang diangkat oleh masing-masing media online sedikit terpengaruh oleh kedatangan Presiden Jokowi ke Riau. Ini dilihat dari penurunan banyaknya berita dari Tribunpekanbaru.com dalam memberitakan karhutla sedangkan di Riaupos.co ada peningkatan jumlah berita yang tidak terlalu signifikan. Hal ini disebabkan berdasarkan hasil observasi awal yang peneliti amati bahwasanya berita mengenai karhutla sebelum tanggal 15-17 September 2019 memiliki kuantitas pemberitaan tentang karhutla yang banyak dengan judul-judul yang bombastis sedangkan setelah kedatangan Presiden kuantitas pemberitaan menjadi sedikit menurun dan stabil dengan judul-judul pemberitaan yang relative menggunakan bahasa yang informatif mengenai kinerja pemerintah dalam penangan karhutla untuk Riaupos.com sedangkan untuk Tribunpekanbaru.com menggunakan bahasa-bahasa yang memberikan solusi dalam penangan karhutla.

Dalam pemberitaan terhadap masing-masing media online Riaupos.co dan Tribunpekanbaru.com tidak terlalu berbeda jauh. Berbeda dari sudut pengambilan penulisan beritanya saja. Intinya kedua media online ini sama-sama membuat berita yang pro kepada pemerintah setelah kedatangan Presiden RI yang mana dapat dilihat dari judul-judul berita dan analisis beritanya mengenai usaha, upaya dan solusi yang diambil pemerintah, dimana sebelumnya kedua media online ini sama-sama memberitakan tentang bentuk protes dan kritikan kepada pemerintah.

\section{DAFTAR PUSTAKA}

Bungin, B. (2011). Metodologi Penelitian Kualitatif. Jakarta: Kencana.

Eriyanto. (2011). Analisis Framing: Konstruksi, Ideologi, dan Politik Media,. Yogyakarta: LKiS.

Eriyanto. (2012). Analisis Framing; Konstruksi, Ideologi, dan Politik Media. Yogyakarta: LKiS.

Forest Watch Indonesia. (2015). Kebakaran Hutan dan Lahan: Bukan Bencana Alam, Awal Bencana Ekologi. Diakses pada 20 Oktober 2019, dari Forest Watch Indonesia website: http://fwi.or.id/publikasi/kebakaran-hutan-dan-lahan-bukan-bencana-alam-awalbencana-ekologi/

Hefri Yodiansyah Sekolah. (2017). Komunikasi Politik Media Surat Kabar Dalam Studi Pesan Realitas Politik Pada Media Cetak Riau Pos Dan Tribun Pekanbaru. Jurnal Kajian Komunikasi, 5(1), 11-30.

Jayani, D. H., \& Widowati, H. (2019). Berapa Pengguna Internet di Indonesia? Diakses pada 19 September 2019, dari databoks.katadata.co.id website: https://databoks.katadata. co.id/datapublish/2019/09/09/berapa-pengguna-internet-di-indonesia

Kementerian Komunikasi dan Informatika. (2018). Menkominfo: Baru 100 Portal Berita

Online Terverifikasi. Diakses pada 19 Oktober 2019, dari kominfo.go.id website: 
https://kominfo.go.id/content/detail/12345/menkominfo-baru-100-portal-berita-onlineterverifikasi/0/berita_satker

Kementrian Hukum dan Hak Asasi Manusia Republik Indonesia. Undang-Undang Nomor 32 Tahun 2009 Tentang Perlindungan Dan Pengelolaan Lingkungan Hidup. , Pub. L. No. Nomor 32 Tahun 2009, 7 (2009).

Kementrian Kehutanan. Peraturan Menteri Kehutanan Tentang Pengendalian Kebakaran Hutan. , (2009).

Kementrian Lingkungan Hidup dan Kehutanan. (2019). 10 Provinsi dengan Kebakaran Hutan dan Lahan Terluas 2019.

Khaviqain, L. O. G. G. D. (2019). Konstruksi Media Online Terhadap Pemberitaan Bencana Kabut Asap Di Indonesia (UMM Intitusional Repository). Diakses pada 19 Oktober 2019, dari http://eprints.umm.ac.id/id/eprint/45763

Kriyantono, R. (2012). Teknik Praktis Riset Komunikasi: Disertai Contoh Praktis Riset Media, Public Relations, Advartising, Komunikasi Organisasi, Komunikasi Pemasaran, (6th ed.). Jakarta: Kencana Prenada Media Group.

Ma'ruf, I. (2019). Kapolri: 99 Persen Kebakaran Hutan Disengaja. Diakses pada 19 Oktober 2019, dari inews.id website: https://www.inews.id/news/nasional/kapolri-99-persenkebakaran-hutan-disengaja

Maranatha, E. I., \& Kusmayadi, I. M. (2020). Konstruksi Pemberitaan Kebakaran Hutan dan Lahan pada Tribun Jambi. Jurnal Kajian Jurnalisme, 3(2), 153. https://doi.org/10.24198/ jkj.v3i2.23894

Muliawanti, L. (2018). Jurnalisme Era Digital: Digitalisasi Jurnalisme Dan Profesionalitas Jurnalisme Online. LENTERA: Jurnal Ilmu Dakwah Dan Komunikasi, 2(1). https://doi. org/10.21093/lentera.v2i1.1168

Pamungkas, C. (2017). Global village dan Globalisasi dalam Konteks ke-Indonesiaan. Jurnal Global \& Strategis, 9(2), 245. https://doi.org/10.20473/jgs.9.2.2015.245-261

Pratomo, Y. (2019). APJII: Jumlah Pengguna Internet di Indonesia Tembus 171 Juta Jiwa. Kompas.Com, p. Internet. Diakses pada 19 Oktober 2019, dari https://tekno.kompas. $\mathrm{com} / \mathrm{read} / 2019 / 05 / 16 / 03260037 / a p j i i-j u m l a h-p e n g g u n a-i n t e r n e t-d i-i n d o n e s i a-t e m b u s-$ 171-juta-jiwa

Pujiono. (2015, September 25). Mengapa kebakaran lahan gambut sulit dipadamkan. Beritagar. Id. Diakses pada 19 Oktober 2019, dari https://beritagar.id/artikel/sains-tekno/mengapakebakaran-lahan-gambut-sulit-dipadamkan

Putsanra, D. V. (2019). Apa Itu Karhutla yang Sebabkan Kabut Asap di Sumatera \& Kalimantan? Diakses pada 19 Oktober 2019, dari Tirto.id website: https://tirto.id/apa-itu-karhutlayang-sebabkan-kabut-asap-di-sumatera-kalimantan-eimk

Romli, A. S. M. (2012). Jurnalistik Online: Panduan Mengelola Media Online. Bandung: Nuansa Cendekia.

Rubby, I. (2019). Kabut Asap Parah di Riau, 1.670 Masyarakat Kampar Terjangkit ISPA Artikel ini telah tayang di Tribunpekanbaru.com dengan judul Kabut Asap Parah di Riau, 1.670 Masyarakat Kampar Terjangkit ISPA, dari pekanbaru.tribunnews.com tribunpekanbaru. com website: https://pekanbaru.tribunnews.com/2019/09/10/kabut-asap-parah-di-riau1670-masyarakat-kampar-terjangkit-ispa

Suryani, A. S. (2012). Penanganan Asap Kabut Akibat Kebaran Hutan di Wilayah Perbatasan Indonesia. Aspirasi, 3(1), 59-76. 